7. Reprod. Fert. (1974) 39, 101-104

\title{
DIFFERENCES IN HYALURONIDASE ACTIVITIES AMONG INBRED STRAINS OF MICE AND THEIR POSSIBLE SIGNIFICANCE FOR VARIATIONS IN FERTILITY
}

\author{
R. P. ERICKSON AND HALINA KRZANOWSKA* \\ Department of Pediatrics, University of California-San Francisco, San Francisco, \\ California 94143, U.S.A., and ${ }^{*}$ Department of Animal Genetics and Organic Evolution, \\ Jagiellonian University, Krupnicza 50, 30-060 Krakow, Poland
}

(Received 3rd December 1973)

Braden (1958) demonstrated that inbred strains of mice differ significantly in the proportion of eggs in which the zona pellucida is penetrated by more than one spermatozoon (supplementary spermatozoa). This difference was shown to be dependent on the strain of the male while differences in the rate of dissolution of the cumulus oophorus were dependent on the strain of the female.

These and other properties have been studied in great detail in the low fertility strain KE, maintained by one of us (H.K.), and the results have been compared with those for some other inbred strains of mice. In the KE strain, $30 \%$ of ova remain unfertilized (Krzanowska, 1960) and there is delayed penetration of the vitellus (Krzanowska, 1964). There is a very high incidence of supplementary spermatozoa (Krzanowska, 1970) and the high percentage of abnormal spermatozoa is partly controlled by a Y-linked gene (Krzanowska, 1969). Hyaluronidase and enzymes with proteolytic activity are the best characterized penetration enzymes and it seemed possible that strain-specific variations in their activities might be related to these fertility parameters. Mouse spermatozoa have little or no tryptic-like enzyme as determined by a sensitive radioassay utilizing tosyl arginine methyl ester (TAME) but do have cathepsin D (R. P. Erickson and S. R. Martin, in preparation). The scatter in catheptic activities of fresh material has prevented a meaningful comparison between strains although some"data on freeze-dried material are included. Hyaluronidase activity has been found to vary significantly among strains of mice and these data form the basis of this report.

Hyaluronidase was assayed using acid-albumin precipitation of undegraded hyaluronic acid for quantification in turbidity-reducing units according to Tolksdorf, McCready, McCullagh \& Schwenk (1949). Activities were such that the epididymal and ductus deferens spermatozoa from one male were insufficient and spermatozoa prepared by slicing the epididymal and ductus tissues (Erickson, 1972) of four to ten males had to be pooled for an experimental

Reprint requests to Dr R. P. Erickson. 
determination which included duplicates and controls. This seemed reasonable for genetically identical males from an inbred strain.

Mice of the C57BL/Kw, KE, KP, and CBA/Kw inbred strains were maintained in Krakow. Spermatozoa from about ten males were prepared in a small volume of $0.1 \mathrm{M}-\mathrm{NH}_{4} \mathrm{HCO}_{3}$ and kept at $-18^{\circ} \mathrm{C}$. After freeze-drying, the samples were shipped by ordinary mail. The $T / t^{12}$ and $T / t^{1}$ balanced lethal inbred lines are maintained at the University of California, San Francisco and $t^{1} / t^{12}$ complemented sterile males were produced by crossing these two strains. The $T / t^{6}$, maintained with outcrosses to the $\mathrm{CBAB}_{6} \mathrm{~F}_{1}$ hybrid and the $\mathrm{C} 3 \mathrm{H} / \mathrm{HeJ}, \mathrm{C} 57 \mathrm{BL} / 6 \mathrm{~J}, \mathrm{GBA} / \mathrm{J}$ and $\mathrm{BALB} / \mathrm{CJ}$ mice were obtained from the Jackson Laboratory, Bar Harbor, Maine. The spermatozoa, prepared and

Table 1. Hyaluronidase activities in fresh frozen spermatozoa of various mouse strains

\begin{tabular}{|c|c|}
\hline Strain & Turbidity-reducing units/mg protein $\uparrow$ \\
\hline $\begin{array}{l}\text { Random-bred } \\
\text { Swiss-Webster }\end{array}$ & $4.55 \pm 0.92(7)$ \\
\hline $\begin{array}{l}\text { Inbred } \\
\text { C3H/HeJ } \\
\text { C57BL/6J } \\
\text { CBA/J } \\
\text { BALB/CJ }\end{array}$ & $\begin{array}{l}4 \cdot 05 \pm 1 \cdot 86(4) \\
5 \cdot 84 \pm 1 \cdot 12(4) \\
2 \cdot 20,4 \cdot 76 \\
1 \cdot 44,2 \cdot 88\end{array}$ \\
\hline $\begin{array}{l}\mathrm{T} \text {-allele related } \\
\mathrm{T} / t^{2} \text { (inbred) } \\
\mathrm{T} / t^{6} \text { (uniform background) } \\
\mathrm{T} / t^{1} \text { (inbred) } \\
t^{1} / t^{12} \text { (uniform hybrid) }\end{array}$ & $\begin{array}{l}2 \cdot 49 \pm 0 \cdot 40^{* *}(6) \\
2 \cdot 34 \pm 0 \cdot 28^{*}(4) \\
0 \cdot 234,2 \cdot 66 \\
1 \cdot 92\end{array}$ \\
\hline
\end{tabular}

$\dagger$ Mean \pm S.E. for the pooled samples (no. of pools in parentheses) or values for single pools.

${ }^{*} P<0.02$ against $\mathrm{C} 57 \mathrm{BL} / 6 \mathrm{~J} ; * * P<0.01$ against $\mathrm{C} 57 \mathrm{BL} / 6 \mathrm{~J}$.

washed an additional time in $0.2 \mathrm{~m}$-glucose, $0.05 \mathrm{M}-\mathrm{NaCl}, 0.02 \mathrm{M}-\mathrm{Na}_{2} \mathrm{HPO}_{4}$ and $0.0026 \mathrm{M}-\mathrm{KH}_{2} \mathrm{PO}_{4}$, were pelleted and kept at $-18^{\circ} \mathrm{C}$ until use. Either freeze-dried or fresh-frozen spermatozoa were taken up in distilled water at a concentration of $10^{8} / \mathrm{ml}$ and sonicated for $4 \times 15 \mathrm{sec}$ at $0^{\circ} \mathrm{C}$. The supernatant, following centrifugation at $17,300 \mathrm{~g}$ for $15 \mathrm{~min}$, was used in the assays; 0.25 to $0.5 \mathrm{ml}$ per tube (experimental or control) was required. Assays were carried out in a total volume of $1 \mathrm{ml}$ over a period of 30 to $60 \mathrm{~min}$. Hyaluronic acid and bovine serum albumin were obtained from Sigma Chemical Co., St Louis, Mo. One turbidity-reducing unit was defined as that amount of hyaluronidase which decreased the turbidity-producing capacity of $0.2 \mathrm{mg}$ hyaluronic acid to that of $0.1 \mathrm{mg}$ in $30 \mathrm{~min}$ at $37^{\circ} \mathrm{C}$. The average of the duplicates (the range of difference was from 0 to $35 \%$ with a mean of $16 \%$ ) was determined for each pool. Protein was determined by the method of Lowry, Rosebrough, Farr \& Randall (1951).

As seen in Table 1 , the activities in different pools from one strain have a high variance but several inbred strains of mice varied significantly in their activities. Thus, C57BL/6J had the highest activity, significantly higher than the two $t$-allele stocks on which a large number of determinations were made 
while the random-bred Swiss-Webster and several inbred strains had intermediate ranges. There was a moderate loss of activity in the freeze-dried material but $\mathrm{C} 57 \mathrm{BL} / \mathrm{Kw}$ and $\mathrm{CBA} / \mathrm{K} w$ retained their relative activities (Table 2) despite belonging to different sub-strains. Strains $\mathrm{KE}, \mathrm{KP}$ and $\mathrm{CBA} / \mathrm{Kw}$ all had significantly less activity than $\mathrm{C} 57 \mathrm{BL} / \mathrm{Kw}$, while $\mathrm{KE}$ and $\mathrm{KP}$ had relatively more hyaluronidase than $\mathrm{CBA} / \mathrm{Kw}$. The determination of a small number of cathepsin activities on these pools with ${ }^{125}$ I-haemoglobin did not disclose any trend of variation. A partial correlation of the number of supplementary spermatozoa and the sperm hyaluronidase levels is apparent from Table 2, although $\mathrm{C} 57 \mathrm{BL} / \mathrm{Kw}$ had the most hyaluronidase but not the most supplementary spermatozoa.

Table 2. Hyaluronidase and cathepsin activities with freeze-dried spermatozoa and numbers of supplementary spermatozoa in various mouse strains

\begin{tabular}{|c|c|c|c|c|}
\hline \multirow{2}{*}{ Strain } & \multirow{2}{*}{$\begin{array}{c}\text { Hyaluronidase } \\
\text { turbidity-reducing } \\
\text { units/mg protein } \dagger\end{array}$} & \multirow{2}{*}{ 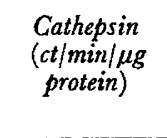 } & \multicolumn{2}{|c|}{$\begin{array}{l}\% \text { eggs containing } \\
\text { supplementary sperm. }\end{array}$} \\
\hline & & & $K E$ eggs & $C B A$ eggs \\
\hline $\begin{array}{l}\text { C57BL/Kw } \\
\text { KE } \\
\text { KP } \\
\text { CBA/Kw }\end{array}$ & $\begin{array}{l}1 \cdot 70 \pm 0 \cdot 15(7) \\
0 \cdot 40 \pm 0 \cdot 23^{* *}(4) \\
0.51 \pm 0 \cdot 19^{* *}(5) \\
0 \cdot 19 \pm 0 \cdot 19^{* *}(3)\end{array}$ & $\begin{array}{c}181 \pm 16(3) \\
153 \\
104 \pm 12(3) \\
127\end{array}$ & $\begin{array}{l}34 \\
44 \\
24 \\
14\end{array}$ & $\begin{array}{l}14 \\
26 \\
6\end{array}$ \\
\hline
\end{tabular}

$\dagger$ Mean \pm S.E. for the pooled samples (no. of pools in parentheses). ** $P<0.01$ against $\mathrm{C} 57 \mathrm{BL} / \mathrm{Kw}$.

Braden (1958) has shown that dissolution of the cumulus occurs more rapidly in mated C57BL mice than in A, CBA, or R III mice and between-strain crosses suggested that this phenotype was primarily controlled by the genotype of the female. The time of dissolution of the cumulus by exogenous hyaluronidase in vitro was similar for C57BL and CBA strains (Krzanowska, 1972). The sperm hyaluronidase might, therefore, have some other rôle in contributing to the male-determined frequency of supplementary spermatozoa, or the partial correlation of sperm hyaluronidase activities with the numbers of supplementary spermatozoa might be fortuitous.

The biochemical basis for segregation distortion in $t$-allele mice is not yet understood (Gluecksohn-Waelsch \& Erickson, 1970). The data in Table 1 suggest that sperm hyaluronidase is not adversely affected by $\mathrm{T}$-alleles, even in sterile complemented males $\left(t^{1} / t^{12}\right)$.

This work was supported by the Population Council, New York, N.Y. Miss Susan Martin provided excellent technical assistance.

\section{REFERENGES}

BRADEN, A. W. H. (1958) Variation between strains of mice in phenomena associated with sperm penetration and fertilization. F. Genet. 56, 37 .

Erickson, R. P. (1972) Alternative modes of detection of H-2 antigens on mouse spermatozoa. In The Genetics of the Spermatozoon, p. 191. Eds. R. A. Beatty and S. Gluecksohn-Waelsch. Edinburgh. 
Gluecksohn-WaElsch, S. \& Erickson, R. P. (1970) The T-locus of the mouse: implications for mechanisms of development. Curr. Topics Devl Biol. 5, 281.

KRzANowsKa, H. (1960) Studies on heterosis. II. Fertilization rate in inbred lines of mice and their crosses. Folia biol., Kraków, 7, 269.

Krzanowska, H. (1964) Time interval between copulation and fertilization in inbred lines of mice and their crosses. Folia biol., Kraków, 12, 231.

Krzanowska, H. (1969) Factor responsible for spermatozoan abnormality located on the Y chromosome in mice. Genet. Res. 13, 17.

KRzANOWsKa, H. (1970) Relation between fertilization rate and penetration of eggs by supplementary spermatozoa in different mouse strains and crosses. F. Reprod. Fert. 22, 199.

KRZANOWsKA, H. (1972) Rapidity of removal in vitro of the cumulus oophorus and the zona pellucida in different strains of mice. J. Reprod. Fert. 31, 7.

Lowry, O. H., Rosebrough, N. J., FArR, A. L. \& Randall, R. J. (1951) Protein measurement with the Folin phenol reagent. F. biol. Chem. 193, 265.

Tolksdorf, S., MaCready, M. H., McGullagh, D. R. \& Schwenk, E. (1949) The turbidimetric assay of hyaluronidase. F. Lab. clin. Med. 24, 74. 